\title{
症例報告
}

\author{
室房伝導を伴う胎児期心室頻拍症から \\ 生後高度房室ブロックとなった 1 例 \\ 白水 優光 $^{1)}$, 宗内 淳 $^{1)}$, 杉谷 雄一郎 ${ }^{1)}$, 岡田 清吾 ${ }^{1)}$, \\ 川口 直樹 ${ }^{1)}$, 飯田 千晶 ${ }^{1)}$, 渡邊 ま夕江 ${ }^{1)}$, 川上 剛史 ${ }^{2)}$ \\ 1) 独立行政法人地域医療機能推進機構九州病院小児科 \\ 2) 独立行政法人地域医療機能推進機構九州病院産婦人科
}

\section{Advanced Atrioventricular Block after Postnatal Cardioversion for Fetal Ventricular Tachycardia: A Case Report}

\author{
Hiromitsu Shirozu ${ }^{1}$, Jun Muneuchi ${ }^{1)}$, Yuichiro Sugitani ${ }^{1)}$, Seigo Okada ${ }^{1)}$, \\ Naoki Kawaguchi ${ }^{1)}$, Chiaki Iida ${ }^{1)}$, Mamie Watanabe ${ }^{1)}$, and Takeshi Kawakami ${ }^{2)}$ \\ 1) Department of Cardiology, Japan Community Healthcare Organization Kyushu Hospital, Fukuoka, Japan \\ 2) Department of Gynecology and Obstetrics, Japan Community Healthcare Organization Kyushu Hospital,
}

Fukuoka, Japan

\begin{abstract}
We present a neonatal girl who developed complete atrioventricular block after postnatal cardioversion for fetal ventricular tachyarrhythmia. A pregnant women was referred at 39 gestational weeks due to fetal tachyarrhythmia of $180 \mathrm{bpm}$ and without atrioventricular (AV) dissociation. Subsequently, a baby girl was delivered weighing 3,130 g. Electrocardiography revealed wide QRS tachycardia with left axis deviation, and the esophageal leads revealed a short $\mathrm{RP}^{\prime}$ duration without AV dissociation. However, AV dissociation was overt after injecting adenosine triphosphate, which suggested ventricular tachycardia. Cardioversion stopped the ventricular tachycardia but led to atrioventricular block with fascicular block (P rate $138 \mathrm{bpm}$, QRS rate $75 \mathrm{bpm}$ ), and the resulting hypotension $(32 / 15 \mathrm{mmHg})$ was improved by dopamine administration. Echocardiography revealed a left ventricular end-diastolic diameter of $16.8 \mathrm{~mm}$ and an ejection fraction of $30 \%$. Serial electrocardiography revealed a second-degree atrioventricular block at 15 hours after birth that reverted to sinus rhythm at day 2 after birth. She was discharged on day 48 after birth. Holter electrocardiographic monitoring did not shown recurrence of either the ventricular tachycardia or the atrioventricular block. The present case was unique because advanced atrioventricular block due to overdrive suppression in the His-Purkinje conduction system followed ventricular tachycardia with ventriculoarterial conduction.
\end{abstract}

Keywords: fetal arrhythmia, ventricular tachycardia, atrioventricular block, ventriculatrial conduction

胎児期発症心室頻拍の新生児例において, 生後, 電気的除細動による心室頻拍停止後に一過性高度房 室ブロックとなった 1 例を経験したので報告する．在胎 39 週 3 日の胎児心エコー図検査で心拍数 180 回/分の房室解離のない胎児頻拍症を指摘され当院産科へ紹介となり, そのまま娭出となった. 出生体 重は 3,130 g であった. 12 誘導心電図では左軸偏位・幅広い QRS 波を伴う short RP'頻拍であり, アデ ノシン三リン酸急速静注により房室解離が見られたので心室頻拍症と診断した. 電気的除細動により 心室頻拍は停止したが，脚枝ブロックを伴う高度房室ブロック（P 波 138 回/分, QRS 波 75 回/分）と なった．血圧 32/15 mmHg であったがドパミン投与により血圧は回復した．心エコー図検査では左室

2018 年 9 月 21 日受付, 2019 年 4 月 3 日受理

著者連絡先：干806-8501 福岡県北九州市八幡西区岸の浦 1-8-1 独立行政法人地域医療機能推進機構九州病院小児科 宗内 淳 doi: $10.9794 /$ jspccs. 35.188 
拡張末期径 $16.8 \mathrm{~mm}$, 左室駆出率 $30 \%$ であった. 生後 15 時間後より 2 度房室ブロックを経て, 生後 2 日には正常洞調律へ復し, 生後 48 日に退院した. 経過中および退院後のホルター心電図検査でも心室 頻拍・房室ブロックの再発は認めなかった. 胎児期には心室頻拍による逆行性室房伝導を認めていた にもかかわらず，心室頻拍停止後に His-Purkinje 伝導系の高頻度駆動抑制（overdrive suppression）現 象のため高度房室ブロックとなった希な経過であった.

\section{緒 言}

胎児頻拍症は上室性頻拍, 特に副伝導路を介した房 室回帰性頻拍や心房粗動等, が多く, 心室頻拍は極め て稀である ${ }^{1,2)}$. 胎児頻拍症の診断は胎児心エコー図 検査や胎児心磁図等によって行われる ${ }^{2-5)}$. 胎児心工 コー図検査では胎児四腔像から得られる $\mathrm{M}$ モード法 またはドプラー法により心房・心室収縮を同定するこ とで房室解離の有無を診断し, 基本的には房室解離が なければ上室性頻拍症, 房室解離があれば心室頻拍症 と診断する. 今回, 胎児心エコー図検査で房室解離を 伴わない頻拍症であったが, 生後, アデノシン三リン 酸 (ATP) 投与により房室解離が顕在化したため心室 頻拍症と診断し, なおかつ電気的除細動後に高度房室 ブロックとなった非常に稀な経過を呈した 1 例を経験 したので報告する.

\section{症 例}

母体 38 歳（経妊 0 回, 経産 0 回）が妊娠 39 週 3 日に胎動減少を主訴に管理中産科を受診した。 その前 日に定期妊婦健診を受けていたが胎児心拍は異常な く，それまでの経過でも胎児異常は指摘されなかっ た．胎児心拍モニタリングで胎児頻拍症を疑われ（心 拍数 180 回/分）当院産科へ紹介となった. 胎児心工 コー図検査では, 四腔像から得られた M モード法に よる心房・心室収縮評価では房室解離を認めなかっ たため, 上室性頻拍症を疑った（Fig. 1). 胎児心胸比 0.39 であり, 心血管構造に異常はなかった. 臍帯血逆 行性血流は認めなかったものの, 軽度腹水と皮下浮腫 を認めた. 児の成熟は十分得られていると判断し児娩 出の方針とし, 同日に緊急帝王切開（メピバカイン塩 酸塩による脊髄くも膜下硬膜外併用麻酔）により出生 した. 出生体重 $3,130 \mathrm{~g}$, Apgar スコア 1 分 1 点で自発 呼吸に乏しく, 直ちに人工呼吸管理として NICU入 室となった。 心拍数 189 回/分，血圧 30/12 mmHg, 酸素飽和度 $100 \%$ （吸入酸素分圧 $80 \%$ ）だった。 心 音は軽度減弱し, 肝 $3 \mathrm{~cm}$ と腫大しており, 軽度の皮 下浮腫と末梢チアノーゼを認めた. 静脈血ガス分析 では $\mathrm{pH} 7.074, \mathrm{pCO}_{2} 77.4 \mathrm{mmHg}, \mathrm{HCO}_{3} 22.6 \mathrm{mmol} /$
$\mathrm{L}$ ，Base excess $-8.4 \mathrm{mmol} / \mathrm{L}$ ，乳酸 $120 \mathrm{mg} / \mathrm{dL}$ （基準 值 4.5-14.4 mg/dL) であった. 胸部 X 線では心胸比 $48 \%$, 肺野にうっ血は認めなかった. 12 誘導心電図 検査では心拍数 189 回/分, 幅の広い QRS 波が認めら れ， QRS 軸は左軸偏位 ( -87 度), 右脚ブロック型で あった．食道誘導心電図により $\mathrm{P}$ 波を記録したとこ ろ, QRS 波と $\mathrm{P}$ 波は 1:1 伝導であり房室解離はなかっ た（Fig. 2). 左軸偏位を伴う幅の広い QRS 波は心室 頻拍症を疑う所見であったものの房室解離を伴わない ことから, 更に診断を深めるために ATP 急速静注を 行ったところ房室解離所見が見られた（Fig. 3). 経胸 壁心エコー図検査では心血管構造異常はなく, 左室 拡張末期径 $16.8 \mathrm{~mm}$, 左室駆出率 $30 \%$ であった。以 上から室房伝導 (1:1) を伴った心室頻拍症と診断し た。 な押，児の刺激伝導系へ影響する薬剤の母体や児 への使用はなかった.

生後 30 分で, 電気的除細動（2J）により心室頻 拍は停止したが, 直後に左軸偏位, 左脚ブロック 型の QRS 波形を伴う高度房室ブロック（P 波 138 回/分, QRS 波 78 回/分）となった（Fig. 4). 血圧 $32 / 15 \mathrm{mmHg}$, 酸素飽和度 $98 \%$ （室内気）であり, 静脈血ガス分析では $\mathrm{pH} 7.522, \mathrm{pCO}_{2} 26.5 \mathrm{mmol} / \mathrm{L}$, $\mathrm{HCO}_{3} 2.17 \mathrm{mmol} / \mathrm{L}$, Base excess $-0.3 \mathrm{mmol} / \mathrm{L}$, 乳酸 $103 \mathrm{mg} / \mathrm{dL}$ であった. ドパミン投与を開始し, 心拍 数 108 回/分, 血圧 61/37 mmHg と回復したため, 緊 急経皮的・経静脈的ペーシングの準備を行いつつ経過 観察した. 血液検查所見では総蛋白 $3.5 \mathrm{~g} / \mathrm{dL}$ （基準值 6.6-8.1 g/dL)，アルブミン $2.2 \mathrm{~g} / \mathrm{dL}$ （基準值 4.1-5.1 g/ $\mathrm{dL}$ ), AST $1720 \mathrm{IU} / \mathrm{dL}$ (基準值 13-30IU/dL), ALT $201 \mathrm{IU} / \mathrm{dL}$ （基準值 7-23 IU/dL)，LDH $6483 \mathrm{IU} / \mathrm{dL}$ （基 準值 124-222 IU/dL)，クレアチンキナーゼ585 IU/ $\mathrm{dL}$ （基準值 41-153 IU/dL)，尿素窒素 $11 \mathrm{mg} / \mathrm{dL}$ （基 準值 8-20 mg/dL)，クレアチニン $0.70 \mathrm{mg} / \mathrm{dL}$ （基準 值 $0.46-0.79 \mathrm{mg} / \mathrm{dL}$ ), 白血球数 $25.2 \times 10^{9} / \mathrm{L}$, モグ ロビン $18.2 \mathrm{~g} / \mathrm{dL}$, 血小板数 $152 \times 10^{9} / \mathrm{L}$ であった. 生後 15 時間より, 2 度房室ブロックとなって時々 房室伝導が認められるようになり, 循環状態も安定 してきた. 左軸偏位, 右脚ブロック型 QRS 波形か ら二脚枝ブロックと考えられた. 生後 2 日目までに は完全に正常洞調律へ復し, 心拍数 117 回/分, 血 


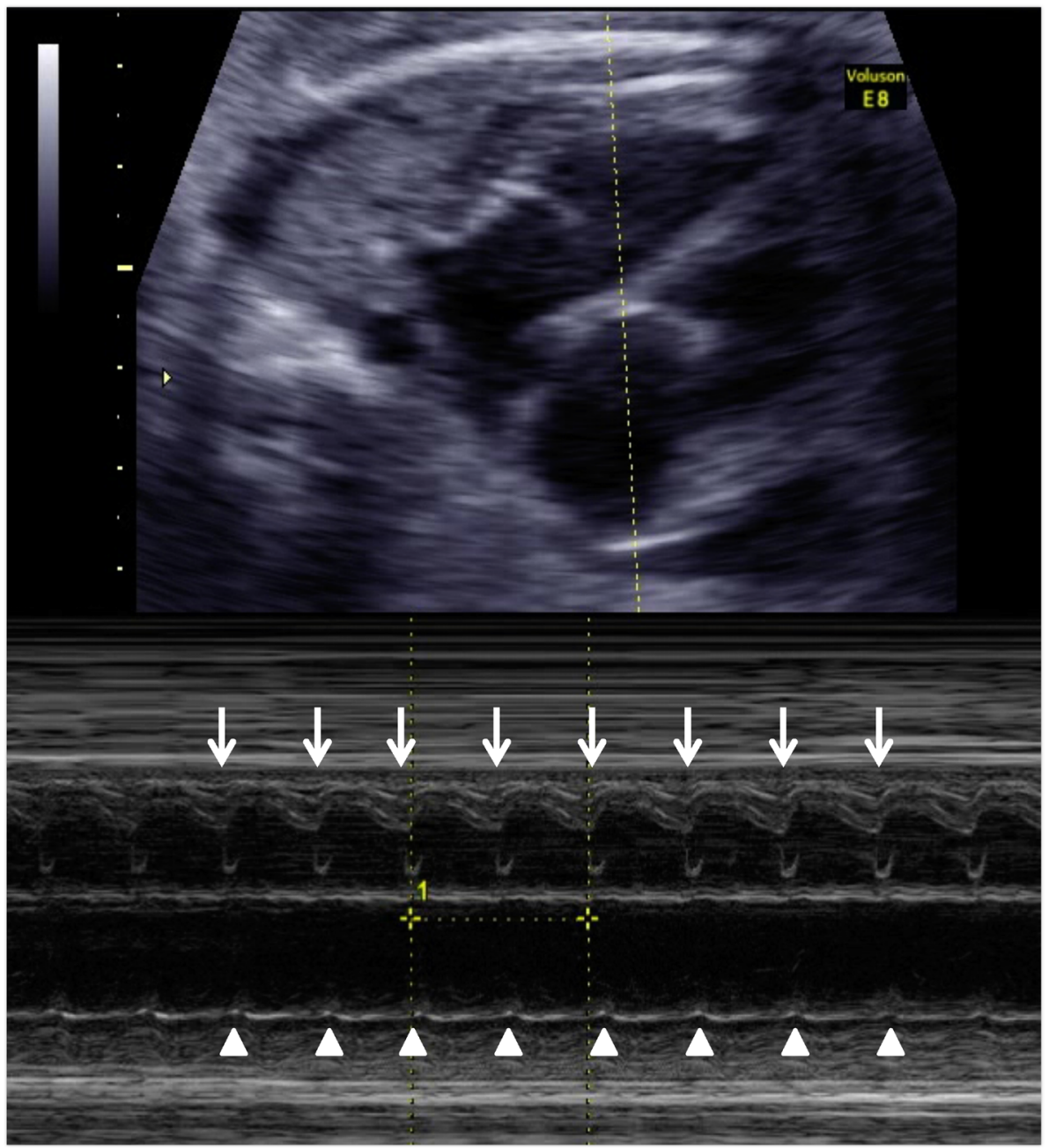

Fig. 1 Fetal echocardiography showed atrioventricular dissociation on a M-mode image (below) Arrows and arrow heads showed ventricular and atrial contractions, respectively.

圧 54/30 mmHg であり，排尿も良好であった，心工 コー図検査では左室拡張末期径 $19.0 \mathrm{~mm}$, 左室駆出率 45\%であった。胸骨傍短軸像で右室肥大 1 度であり, 動脈管開存による左右短絡血流速度から得られた推定 圧較差は $10 \mathrm{mmHg}$ であったので軽度肺高血圧合併と 診断した。その他心内構造異常や有意な房室弁異常は なく, 正常起始冠動脈であった。生後 4 日目には抜管 し, 生後 12 日目にドパミンは中止した. 生後 2 週目, 12 誘導心電図は正常洞調律で PR 時間延長, QRS 幅 延長，QT 時間延長もなく，ホルター心電図検査でも 心室頻拍あるいは房室ブロックいずれも認めなかった (Fig. 5). 生後 36 日目の心エコー図検査では左室拡張 末期径 $21 \mathrm{~mm}$, 左室駆出率 $52 \%$ と心収縮は回復し, 動脈管は閉鎖していた．血清クレアチンキナーゼ值の 推移をみると，生後 1 日目は電気的除細動の影響もあ り $1,207 \mathrm{IU} / \mathrm{dL}$ であったが，生後 2 日目には $484 \mathrm{IU} /$
$\mathrm{dL}$ と低下し，生後 1 週間目には基準值へ回復してい た. 血液中ウイルス分離ではウイルス検出はなく, 抗 SS-A/SS-B 抗体も陰性, タンデムマススクリーニ ング検査も陰性であった。生後 38 日目, 投薬なしで 退院，外来経過観察とした。現在，生後 1 歳となった が，成長発達は良好であり，心室頻拍や房室ブロック いずれも再発はなく心機能も良好である.

\section{考察}

胎児期発症の室房伝導（1:1）を伴う心室性頻拍に 対して, 生後, 電気的除細動による心室頻拍停止後に 左脚ブロック QRS 波形を伴う一過性高度房室ブロッ クとなり, 経時的に右脚ブロックから洞調律への回復 を観察できた 1 例を経験した。

胎児期から新生児期において，心房・心室収縮比が 


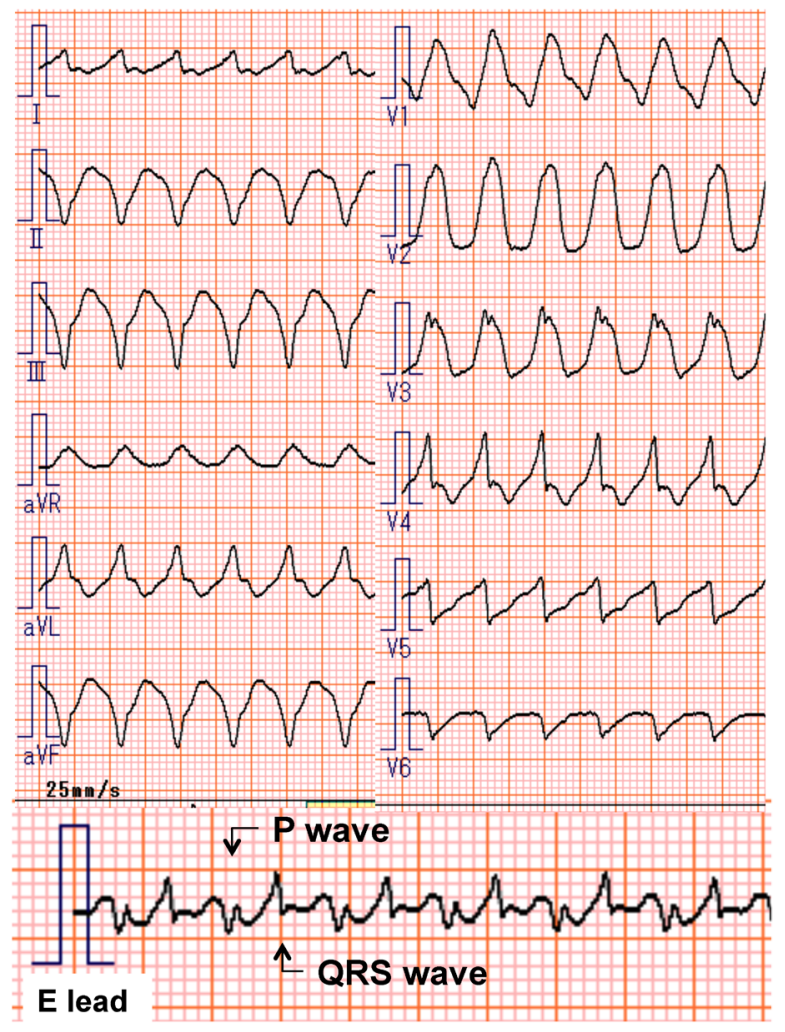

Fig. 2 A 12-lead electrocardiogram at birth showed wide QRS tachycardia with the heart rate of 189 beats per minute and left deviation of QRS axis

A electrocardiogram on the esophageal lead (below: E lead) revealed 1:1 atrioventricular conduction, which indicated a possibility of supraventricular tachycardia.

$1: 1$ で対応する頻拍は, 副伝導路に関連した房室回帰 性頻拍が最も多く, 房室結節回帰性頻拍, 永続性接合 部回帰頻拍, 異所性心房頻拍も考慮される. 逆行性伝 導が 1:1 で対応する心室頻拍や房室接合部頻拍は非 常に稀である ${ }^{1,2,6,7)}$. Fouron は胎児頻拍症 30 例の室 房時間に基づく診断法を報告している，短い室房時間 （室房時間＜房室時間）の場合は房室回帰性頻拍に代 表されるリエントリー性頻拍または異所性心房頻拍, 長い室房時間（室房時間＞房室時間）の場合は洞性頻 脈あるいは永続性接合部回帰頻拍, 室房時間=房室時 間の場合は異所性心房頻拍であったと報告し，30 例 中 1 例のみ心室頻拍であった ${ }^{7}$ 。本例の胎児心エコー 図検査では室房時間＜房室時間であったことから房室 回帰性頻拍が最も考えられ，本例のような $1: 1$ 室房 伝導の心室頻拍は既報なく極めて希少と考える ${ }^{7)}$.

胎児期/新生児期発症心室頻拍は, 先天性 QT 延長 症候群に代表されるイオンチャネル病や，心筋炎，心

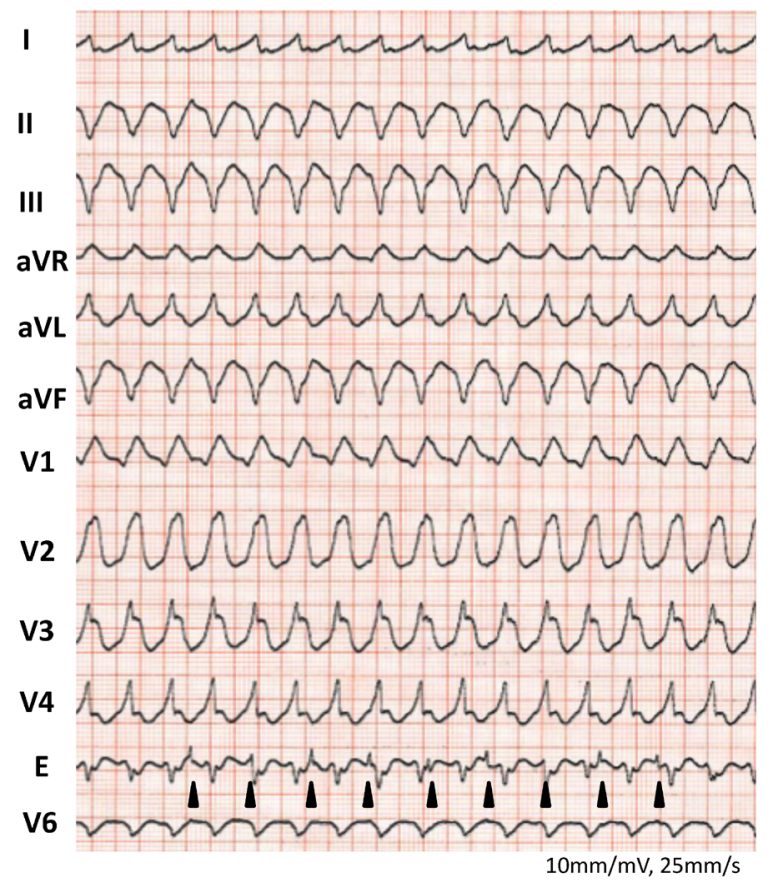

Fig. 3 A 12-lead electrocardiogram just after the intravenous administration of ATP showed atrioventricular dissociation on the esophageal lead (E lead)

Arrow heads indicated $P$ waves.

筋症，心筋虚血等の心筋疾患，また代謝疾患等の基礎 疾患のもとに発症することが多く，特発性心室頻拍は 非常に稀である ${ }^{1,6)}$ 。冠動脈疾患，心筋炎，代謝疾患 等は後日実施した追加検査で否定され，本症例では， 出生直後 12 誘導心電図において左軸偏位・右脚ブ ロック型心室頻拍であったことから，His-Purkinje 伝 導系を介した束枝回帰頻拍（fascicular reentry tachycardia)，いわゆるべラパミル感受性心室頻拍の可能性 も考慮された．新生児期発症べラパミル感受性頻拍 症もこれまで数例の報告しかない ${ }^{8,9)}$. ベラパミル感 受性心室頻拍としても QRS 幅が広いことから，背景 には心筋虚血や伝導障害があっとことも推察された。

また本症例では頻拍レートが 180～190/分であり，胎 児期心室頻拍では頻拍レート 200/分未満であっても 急性循環不全を生じることがあるため，注意深い観察 が必要であり，胎動低下や胎児水腫の徴候が見られた 際には躊躇なく婏出を考慮する必要があると考えられ た.

一方，本症例では胎児期より心室頻拍中の室房伝導 は非常に良好であったものの，心室頻拍停止後に高度 房室ブロックとなる特異な経過をたどった。房室伝導 能が必ずしも室房伝導能とは関連しないという報告 


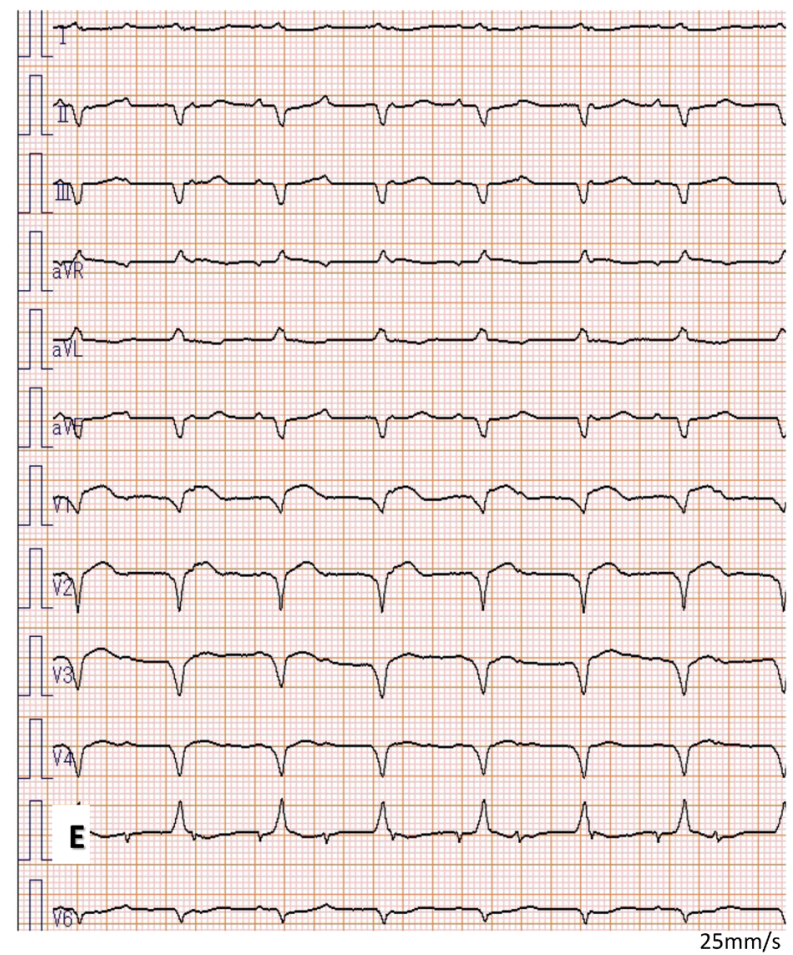

Fig. 4 A 12-lead electrocardiogram after energy application of cardioversion showed complete atrioventricular block
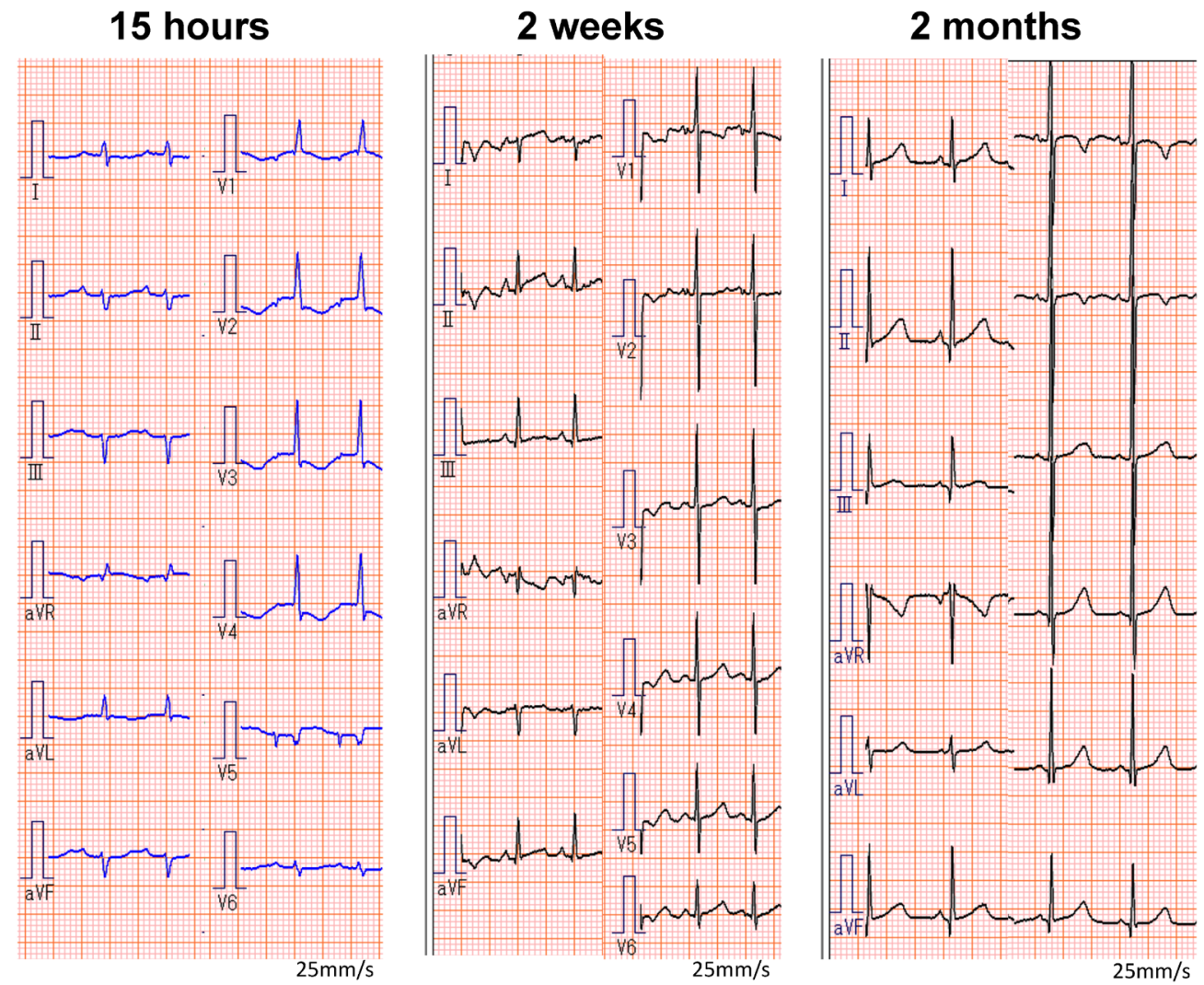

Fig. 5 12-lead electrocardiograms at 15 hours, 2 weeks and 2 months after birth were shown The baseline rhythm was recovered to the normal sinus rhythms until 15 hours after birth. 
から, 房室伝導に何らかの異常があったと推測され る ${ }^{10)}$. 本症例で観察された現象は His-Purkinje 伝導 系の高頻度駆動抑制（overdrive suppression）現象で 説明される. Takahashi らは犬の動物実験において, 冠動脈前中隔枝を閉塞させた状態で心房と心室にそれ ぞれ高頻度刺激を加えた場合に, 心室高頻度では刺激 終止後に房室ブロックが生じ, かつその現象は刺激頻 度・時間依存性であった一方, 心房高頻度刺激では房 室ブロックは生じなかったと報告した ${ }^{11)}$ 。 心室高頻 度刺激中は室房伝導が認められたことから, 心筋虚血 を背景として His 束遠位から Purkinje 系にかけての 高頻度駆動抑制現象であると考察している. また洞調 律時に左脚ブロック型を呈する症例に右室流出路高頻 度刺激後 His 束遠位側のブロックを生じた症例も散 見され，いずれも His-Purkinje 伝導系の fatigue phenomenon すなわち高頻度駆動抑制としている ${ }^{12,13)}$. 本症例では, 心室頻拍により冠潅流低下を生じていた ことに加え, 1:1 室房伝導により His-Purkinje 伝導 系の高頻度駆動抑制現象が生じ，心室頻拍停止後に一 過性高度房室ブロックが生じたと考えられた。また心 室頻拍停止後の QRS 波形の変化に注目すると, 左軸 偏位・左脚ブロック型の幅の広い QRS 波形であり, 15 時間後には左軸偏位・右脚ブロック型の QRS 波形 へ，2 週間後には右軸偏位となり，2 出月後には正常 軸へ変化していることから，それぞれ 3 脚枝ブロッ ク, 2 脚枝ブロック, 右脚ブロックへと変化し, 最終 的に洞調律へ復した際は正常な His-Purkinje 伝導へ 回復したものと推察され, このことも前述の推察を示 唆する，房室伝導障害を生じる疾患にはミトコンドリ ア心筋症や筋緊張性筋ジストロフィー等が知られてい るが，本症例では臨床経過から否定的であった ${ }^{14,15)}$. 高頻度駆動抑制現象の病態は未だ不明な点も多いが, 洞結節における高頻度駆動抑制は周知の現象であり, 高頻度刺激によるアセチルコリンの放出, カリウムの 細胞外への放出, ナトリウムポンプの不活性化, 細 胞膜のカルシウム交換の変化等が影響していると考え られている ${ }^{16)}$. 前述の Takahashi らの動物実験では His-Purkinje 伝導系高頻度駆動抑制現象はイソプロ テレノールで促進され，ベラパミルで抑制される傾向 があったことから, カルシウムイオンがこの現象に影 響を及ぼしていることが推測された ${ }^{11)}$.

\section{結語}

胎児期発症の室房伝導を伴う心室頻拍症において, 生後洞調律へ回復後に一過性高度房室ブロックとなっ
た症例を経験した。 心室頻拍による冠潅流低下を背景 とした His-Purkinje 伝導系高頻度駆動抑制現象が示 唆された．胎児頻拍症の診断に際しては, 胎児心室頻 拍の可能性も考慮し注意深い観察が必要である.

\section{利益相反}

著者全員において開示すべき利益相反はありません.

\section{著者の貢献度}

白水優光は初稿を作成し, 宗内淳は論文全体の構成や修正に加 担しました。杉谷雄一郎と岡田清吾は実質的診療にあたりデー タの収集を行いました. 川口直樹と飯田千晶は生理学的検查の データ収集を行いました。渡邊まみ江は最終稿の確認をしまし た. 川上剛史は胎児期データの収集を行いました。

\section{付 記}

第 22 回日本小児心電図学会学術集会において発表した内容で, 日本小児循環器学会より投稿推薦をいただきました.

\section{引用文献}

1) Krapp M, Kohl T, Simpson JM, et al: Review of diagnosis, treatment, and outcome of fetal atrial flutter compared with supraventricular tachycardia. Heart 2003; 89: 913917

2) Bravo-Valenzuela NJ, Rocha LA, Machado Nardozza LM, et al: Fetal cardiac arrhythmias: Current evidence. Ann Pediatr Cardiol 2018; 11: 148-163

3) Simpson J: Fetal arrhythmias, in Allan L, Hornberger L, Sharland G (eds): Textbook of Fetal Cardiology. London, Greenwich Medical Media, 2000, pp 423-437

4) Zhao H, Strasburger JF, Cuneo BF, et al: Fetal cardiac repolarization abnormalities. Am J Cardiol 2006; 98: 491-496

5）堀米仁志，Wakai RT: 胎児心磁図の基礎と臨床応用. 日 小览循環器会誌 $2003 ; 19: 468-475$

6) Clark JM, Case CL: Fetal arrhythmias, in Gillette PC, Garson A (eds): Clinical Pediatric Arrhythmias. Philadelphia, W. B. Saunders Company, 1999, pp 293-302

7) Fouron JC: Fetal arrhythmias: The Saint-Justine hospital experience. Prenat Diagn 2004; 24: 1068-1080

8) Ozer S, Allen S, Schaffer MS: Adenosine- and verapamil-sensitive ventricular tachycardia in the newborn. Pacing Clin Electrophysiol 2001; 24: 898-901

9) Dhala A, Lewis DA, Garland J, et al: Verapamil sensitive incessant ventricular tachycardia in the newborn. Pacing Clin Electrophysiol 1996; 19: 1652-1654

10) Inoue T, Kobayashi K, Fukuzaki H: Ventriculo-atrial conduction in patients with normal and impaired atrio-ventricular conduction. Jpn Heart J 1985; 26: 707-714

11) Takahashi N, Gilmour RF Jr, Zipes DP: Overdrive suppression of conduction in the canine His-Purkinje system after occlusion of the anterior septal artery. Circulation 1984; 70: 495-505 
12) Barold SS, Barold HS: Demonstration of a His-Purkinje fatigue phenomenon with programmed stimulation of the right ventricular outflow tract. J Interv Card Electrophysiol 2000; 4: 489-491

13) Sasano T, Okishige K, Azegami K, et al: Transient complete atrioventricular block provoked by ventricular pacing in a patient with nonsustained ventricular tachycardia. J Electrocardiol 1999; 32: 185-190
14) 武田充人：ミトコンドリア心筋症. 日小児循環器会誌 2017; 33: 287-297

15) Lau JK, Sy RW, Corbett A, et al: Myotonic dystrophy and the heart: A systematic review of evaluation and management. Int J Cardiol 2015; 184: 600-608

16) Josephson ME 著. 杉本恒明訳：洞結節機能. 臨床心臓 電気生理学—手技と解釈一. 第 2 版. 新潟, 西村出版, 1998, pp 63-85 